\title{
Corticosteroid treatment, serum lipids and coronary artery disease
}

\author{
D. B. JEFFERYS \\ B.Sc., M.R.C.P.
}

\author{
M. H. LESSOF \\ M.D., F.R.C.P.
}

\author{
M. B. MatTock \\ Ph.D.
}

\section{Department of Medicine, Guy's Hospital, London Bridge SEI 9RT}

\begin{abstract}
Summary
Serum lipids and the cholesterol concentrations in the high density lipoprotein (HDL) fractions were measured in patients receiving long-term corticosteroid treatment for connective tissue disorders and asthma. Patients who were not receiving corticosteroid treatment had blood lipid levels which did not differ from those of healthy people. However, female (but not male) patients who had received prednisolone for a mean period of 3.1 years had a significant elevation in total cholesterol and a large decrease in HDL cholesterol. It seems possible that high levels of corticosteroids may increase the incidence of premenopausal ischaemic heart disease in females.
\end{abstract}

\section{Introduction}

Corticosteroids are frequently used in the longterm management of connective tissue disorders and occasionally in patients with asthma and sarcoid. In addition to the traditional complications of this treatment, Kalbak (1972) showed an increase in peripheral atherosclerosis during corticosteroid treatment for rheumatoid arthritis. As compared to well matched controls, Bulkley and Roberts (1975) found an increased incidence of coronary atherosclerosis at post-mortem in 36 patients who had received corticosteroids for a variety of conditions including systemic lupus and rheumatoid arthritis. An increased incidence of coronary artery disease has also come to be recognized in renal transplant patients on corticosteroids (Evans and Ghosh, 1979).

The mechanism for this accelerated atherosclerosis is unclear. El-Shaboury and Hayes (1973) showed that both triglycerides and cholesterol were increased in 100 female asthmatics on long-term corticosteroid treatment. Current interest in lipid metabolism centres on the high density lipoproteins and their inverse relationship to ischaemic heart disease (Gordon et al., 1977). These levels may be particularly significant if, as has been suggested, high density lipoproteins are responsible for transferring cholesterol out of the tissue and back into the general metabolic pool, where it may be catabolized.

In this study the authors have looked at the longterm effects of corticosteroids on HDL cholesterol. They have studied 3 groups: patients who are receiving corticosteroids; age-, sex- and disease-matched patients who are not receiving such treatment; and healthy age- and sex-matched controls.

\section{Patients and methods \\ Subjects}

The serum total cholesterol, triglycerides and HDL cholesterol were measured for 16 pre-menopausal female patients (age range 18-34 years) and 15 males (ages 24-38 years) who were all receiving long-term corticosteroid treatment. The body weights were all within $5 \%$ of the predicted weight from standardized life assurance tables. Three of the females were taking an oral contraceptive, whilst only 2 of the males and none of the females were cigarette smokers. None had a known family history of hyperlipidaemia. The average dose of prednisolone was $17.0 \mathrm{mg} /$ day for the females and $17.2 \mathrm{mg}$ for the males. The mean duration of treatment was $3 \cdot 1$ years for the females and 3.4 years for the males.

The patients studied were all in remission from their disease at the time of investigation. This was judged from clinical impression and from sedimentation rates, biochemical profiles and respiratory function tests.

Three of the patients with Behçet's syndrome were taking azathioprine $50 \mathrm{mg}$ twice/day, one of the rheumatoids was taking naproxen $200 \mathrm{mg}$ thrice/day and one patient with urticarial vasculitis was receiving cimetidine $400 \mathrm{mg}$ at night. Apart from the asthmatics, who were using bronchodilator aerosols, the steroid patients were on no other regular medications. In the control group 3 patients were taking azathioprine $100 \mathrm{mg}$ daily.

The conditions for which they were receiving prednisolone were mainly connective tissue disorders, including Behçet's syndrome (13), systemic lupus 
(2), rheumatoid arthritis (4), polyarteritis (2), urticarial vasculitis (2), sarcoidosis (4) and asthma (4). The blood samples were taken after a 14-hr fast.

\section{Methods}

The fasting serum triglyceride and cholesterol concentrations and the cholesterol concentrations of the high density lipoprotein (HDL) fractions were assayed by standard Technicon Autoanalyser II enzymatic methods.

The HDL fraction was measured in the supernatant following specific precipitation from serum of very low density and low density lipoproteins by sodium phosphotungstate and magnesium chloride (Lopes Virella, Stone and Colwell, 1977). It has been confirmed that this method shows good agreement with a reference ultracentrifugal technique of HDL separation (Mattock et al., 1979).

\section{Results}

There was no significant difference between the disease-, age- and sex-matched controls, compared to the healthy controls, in any of the serum lipids (Table 1). A notable difference was found between the male and female patients receiving corticosteroids. The male patients had lower levels of triglycerides and total cholesterol. They had significantly higher levels of HDL cholesterol and of the total cholesterol to HDL cholesterol ratio $(P<0.001)$. Thus long-term corticosteroids appear to reverse the usual higher HDL levels seen in females.

\section{Discussion}

The principal finding of this study was the marked sex difference in the effect of long-term corticosteroid administration on HDL cholesterol. Epidemiological studies of ischaemic heart disease have shown that there is an inverse relationship with HDL cholesterol and that the cholesterol to HDL ratio is one of the most sensitive predictors of coronary artery disease (Miller et al., 1977). $\frac{2}{3}$ In such studies, pre-menopausal women have higher $\stackrel{\circ}{\circ}$ HDL cholesterol concentrations. From the authors' $c$

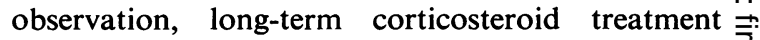
appears to reverse the usual pre-menopausal $\stackrel{?}{?}$ pattern of HDL cholesterol. Indeed, by generally accepted criteria young female patients in this study 음 were likely to have a considerably increased risk $\frac{\bar{m}}{\vec{D}}$ of premature coronary artery disease. In keeping $\mathscr{\unrhd}$ with this, 2 of the female patients have a history of $ळ$ angina pectoris with exercise ECG changes. They $\overrightarrow{0}$ had no family history of ischaemic heart disease.

It was felt important to exclude a primary effect $\vec{\omega}$ of the disease on the serum lipid concentrations, or $\stackrel{\rho}{\circ}$ the influence of other drugs on lipid metabolism. $\stackrel{0}{7}$ The patients studied were all young and were in 3 . remission from their various diseases at the time of investigation. Many had been referred for an os opinion as to whether their corticosteroids could be $V$ reduced or steroid-sparing drugs introduced. The $\overrightarrow{0}$ study was designed to compare the patients on $\vec{\rho}$ steroids with disease-matched controls and healthy $\frac{9}{3}$ subjects. This was facilitated by the fact that the $\vec{C}$ authors were simultaneously looking at a large $\subsetneq$ group of patients with Behçet's syndrome (Lessof et al., 1979). It could be argued that either the $\vec{\emptyset}$ connective tissue disease, or additional drug therapto such as immunosuppressives, would alter the blood. lipids. In fact only 3 patients were receiving, or hat received, azathioprine in addition to the corticosteroids. Three similar patients on azathioprine were therefore included in the disease-matched control group. Since the patients were in remission it was possible to establish well matched controls. Several of the patients were on inappropriately high doses of steroids and these were subsequently reduced without ill effect.

Attention was also paid to the other factors which are known to influence HDL concentrations. Obesity, cigarette smoking and alcohol consumption

TABLE 1. Results

\begin{tabular}{|c|c|c|c|c|c|}
\hline \multicolumn{6}{|c|}{ Serum lipids and high density lipoprotein (HDL) cholesterol all in mmol/l ( \pm s.d.) } \\
\hline Group & & $\begin{array}{l}\text { Corticosteroid } \\
\text { group }\end{array}$ & $\begin{array}{l}\text { Disease-matched } \\
\text { controls }\end{array}$ & $\begin{array}{l}\text { Healthy } \\
\text { controls }\end{array}$ & $\begin{array}{c}\text { Significance, controls } \\
\text { v. steroid group }\end{array}$ \\
\hline $\begin{array}{l}\text { Total triglycerides } \\
(\mathrm{mmol} / \mathrm{l})\end{array}$ & $\begin{array}{l}\text { Male }(n=15) \\
\text { Female }(n=16)\end{array}$ & $\begin{array}{l}1.21(0.42) \\
1.84(0.55)\end{array}$ & $\begin{array}{l}0.90(0.21) \\
0.91(0.29)\end{array}$ & $\begin{array}{l}0.87(0.56) \\
0.90(0.28)\end{array}$ & $\begin{array}{c}\text { NS } \\
P<0.05\end{array}$ \\
\hline $\begin{array}{l}\text { Total cholesterol } \\
(\mathrm{mmol} / \mathrm{l})\end{array}$ & $\begin{array}{l}\text { Male } \\
\text { Female }\end{array}$ & $\begin{array}{l}5.61(0.28) \\
6 \cdot 58(1.04)\end{array}$ & $\begin{array}{l}5 \cdot 33(0 \cdot 31) \\
4 \cdot 81(0 \cdot 81)\end{array}$ & $\begin{array}{l}5.28(0.15) \\
4.93(0.57)\end{array}$ & $\begin{array}{c}\text { NS } \\
P<0.05\end{array}$ \\
\hline $\begin{array}{l}\text { HDL cholesterol } \\
(\mathrm{mmol} / \mathrm{l})\end{array}$ & $\begin{array}{l}\text { Male } \\
\text { Female }\end{array}$ & $\begin{array}{l}1 \cdot 40(0 \cdot 31) \\
1 \cdot 10(0 \cdot 26)\end{array}$ & $\begin{array}{l}1.54(0.15) \\
1.99(0.25)\end{array}$ & $\begin{array}{l}1.50(0.53) \\
1.78(0.35)\end{array}$ & $\begin{array}{c}\text { NS } \\
P<0.01\end{array}$ \\
\hline $\begin{array}{l}\text { Ratio of } \\
\text { Total cholesterol } \\
\text { HDL cholesterol }\end{array}$ & $\begin{array}{l}\text { Male } \\
\text { Female }\end{array}$ & $\begin{array}{l}4 \cdot 00 \\
5 \cdot 98\end{array}$ & $\begin{array}{l}3 \cdot 46 \\
2 \cdot 42\end{array}$ & $\begin{array}{l}3 \cdot 71 \\
2 \cdot 78\end{array}$ & $\begin{array}{c}\text { NS } \\
P<0.001\end{array}$ \\
\hline
\end{tabular}


were found to be similar within the groups. No glucose intolerance was noted. Three of the female patients were taking oral contraceptives but their HDL cholesterol levels were in the range seen in other female patients. It was therefore concluded that the sex difference in HDL concentration was attributable to the corticosteroid treatment rather than to the disease or to other therapy.

The accelerated atherosclerosis seen in patients on long-term corticosteroids has been quoted above. El-Shaboury and Hayes (1973) found a significant increase in serum triglycerides amongst 100 female asthmatics receiving this treatment, and it is of interest that Bulkley and Roberts' (1975) patients with systemic lupus and coronary artery diseaselike lupus patients in general-were predominantly female.

Savdie et al. (1979) have reported a rise in HDL cholesterol after successful renal transplantation but have provided no explanation for this. In view of the authors' own findings and the other evidence quoted here, it seems likely that the reduction in prednisolone dose after successful transplantation may well have been a factor.

Young women usually have higher HDL cholesterol levels than do men and have a low incidence of ischaemic heart disease. The protective effect of female sex hormones is not simple, however, since the contraceptive pill has an opposite effect (Ory, 1977) and so does exogenous sex hormone administration in animals (Jefferys and White, 1973). However the effect of prednisolone on endogenous sex hormones is unknown.

The female patients receiving long-term corticosteroid treatment appear to have the increased risk of developing coronary artery disease, which the male patients do not have. The mechanism for this protection is not clear but may involve changes in endogenous sex hormone production and transport. Whatever the short-term benefits, the present results also emphasize that corticosteroid treatment is a disease in itself and, particularly in female patients, should be kept to a minimum.

\section{References}

BULKLEY, B.H. \& RoBerts, W.C. (1975) The heart in systemic lupus erythematosus and the changes induced in it by corticosteroid therapy. American Journal of Medicine, 58, 243.

El-Shaboury, A.H. \& Hayes, T.M. (1973) Hyperlipidaemia in asthmatic patients receiving long-term steroid therapy. British Medical Journal, 2, 85.

Evans, D.B. \& GHosh, P. (1979) Plasma lipoproteins in renal transplant patients. British Medical Journal, 1, 21.

Gordon, T., Castelli, W., Huortland, M.C., Kannel, W. \& DAWBER, T. (1977) High density lipoprotein as a protective factor against coronary heart disease. American Journal of Medicine, 62, 707.

Gotto, A.M., Miller, N.E. \& Oliver, M.F. (Eds) (1978) High Density Lipoproteins and Atherosclerosis. Excerpta Medica, Amsterdam.

JEFFERYS, D.B. \& White, I.R. (1973) The lipid response to female gonadal hormones in rats. Nutrition Reports International, 8 (3), 201.

KALBAK, K. (1972) The incidence of arteriosclerosis in patients with rheumatoid arthritis receiving long-term corticosteroid therapy. Annals of the Rheumatic Diseases, 31, 196.

Lessof, M.H., JefFerys, D.B., Lehner, T. ,MAtTock, M. \& SAUNDERS, M.D. (1979) Corticosteroids and azathioprine: their use in Behçet's syndrome. Chapt. 22. In: Behçet's Syndrome (Ed. by Lehner, T. \& Barnes, C.G.). Academic Press, London.

Lopes-Virella, M., Stone, P. \& Colwell, J. (1977) Serum high density lipoprotein in diabetic patients. Diabetologia, 13, 285.

Mattock, M.B., Fuller, J.H., Pamela, S.M. \& Keen, H. (1980) Lipoproteins and plasma cholesterol esterification in normal and diabetic subjects. Atherosclerosis (in press).

Miller, N.E., Forde, O.H., Thelle, D.S. \& Mojos, O.D. (1977) High density lipoprotein and coronary heart disease; a prospective case-control study. Lancet, i, 965.

ORY, H.W. (1977) Association between oral contraceptives and myocardial infarction. Journal of the American Medical Association, 237, 2619.

Savdie, E., Gibson, J.C., Stewart, J.H. \& Simons, L.A. (1979) High density lipoproteins in chronic renal failure and after renal transplantation. British Medical Journal, $1,928$. 